\title{
Hersiening van die Chemiewoordeboek
}

\author{
D.F. Louw, Inligtings- en Navorsingsdienste, WNNR, Pretoria
}

Uit Pretoria kom 'n klag oor chemici se gebrek aan belangstelling in die hersiening en uitbreiding van die Chemiewoordeboek wat nou al 15 jaar oud is. Daar is egter ook 'n dringende beroep op dié mense om nou ' $n$ aandeel aan hierdie omvangryke en belangrike taak te neem en nie later te wil kla oor die woordeboek hul vakgebied afgeskeep het of dat verkeerde terme opgeneem is nie.

Die eerste uitgawe van die Suid-Afrikaanse Akademie vir Wetenskap en Kuns se Lys Skeikundige Terme het in 1951 in getikte en afgerolde vorm verskyn. Dit is destyds deur die Akademie se Vaktaalburo uitgegee en het slegs sowat 9000 terme bevat.

In 1955 is 'n hersiene, gedrukte lys deur die Akademie uitgegee en daarin is 13000 terme opgeneem. Prof. S.P.E. Boshoff, destyds Direkteur van die Vaktaalburo, het in daardie uitgawe se voorwoord heelwat aandag bestee aan die herkoms van die grondterme, die Afrikaanse benamingswyse, die reëls by vertaling en transliterasie, en die wyse van woordvorming by die skep van nuwe chemieterme.

Die Vaktaalburo het dit in 1962 nodig gevind om ' $n$ verdere hersiene en uitgebreide uitgawe te laat bewerk. Prof. H.L. de Waal het opgetree as Voorsitter van die Chemiekomitee wat in 1968 die Chemiewoordeboek met 15000 terme onder die Akademie se vleuels uitgegee het.

Vanweë die snelle vooruitgang op die gebied van die chemie het die Akademie se Afdeling Chemie in Julie 1976 'n komitee (met dr. A. Jordaan van die WNNR se Nasionale Chemiese Navorsingslaboratorium as sameroeper) benoem om met die Vaktaalburo oor chemieterminologie te skakel. Teen die einde van daardie jaar het die Vaktaalburo met die Departement Nasionale Opvoeding se Afdeling Terminologie saamgesmelt en hul werksaamhede is binne die Departement se hiërargie voortgesit deur 'n afdeling wat die naam Vaktaalburo behou het.

Die nuwe afdeling het in Julie 1977 besluit dat die hersiening van die Chemiewoordeboek aangepak en die eindproduk onder die Vaktaalburo se naam gepubliseer sal word. 'n Loodskomitee is in die lewe geroep met dr. Jordaan (sameroeper), mnr. J.H. van Niekerk van die Vaktaalburo en dr. D.F. Louw van die WNNR se Inligtings- en Navorsingsdienste as lede. Twee jaar daarna het dr. Jordaan uit Pretoria verhuis en is hy deur dr. Louw as projekleier/sameroeper in die Loodskomitee opgevolg, terwyl prof. C.J. Liebenberg in die vakature benoem is nadat hy met pensioen uit die Universiteit van Pretoria se diens getree het.

Die Loodskomitee het destyds alles in sy vermoë gedoen om samewerking op 'n breë vlak te verkry en sowat 50 chemici is per brief versoek om bydraes te lewer. Deur middel van 'n artikel in CHEMSA is ook 'n algemene oproep tot skeikundiges gerig om aan die omvangryke taak saam te werk. Die eindresultaat was egter teleurstellend, hoewel 'n aantal werklik lofwaardige bydraes ontvang is.

Die WNNR het in 1979 'n voltydse pos geskep vir 'n medewerker om die projekgroep te versterk. 'n Redelik uitgebreide kartoteek met sowat 15000 aanvullende terme is reeds opgebou en Afrikaanse ekwivalente vir die Engelse terme word gesoek en/of saamgestel.

By die bewerking word goeie gebruik gemaak van 'n gerekenariseerde stelsel wat die WNNR vir die uitgee van sy Tekstielwoordeboek (1977) ontwikkel het. Met behulp daarvan is alfabetisering geen probleem nie. Rekenaarlyste kan sonder groot probleme gedruk en vir kommentaar uitgestuur word, terwyl wysigings en toevoegings geredelik ingevoer kan word.

Die grootste probleem is egter daarin geleë dat daar so ' $n$ magdom chemiehandboeke en vakpublikasies is waaruit derduisende vakterme geëkserpeer moet word. Hiervoor ontbreek die mannekrag binne die Loodskomitee se beperkte samestelling. Bowendien is niemand vir die taak so goed toegerus as die vakman wat op 'n besondere gebied gespesialiseer is nie. Die aanbiedinge van hulp deur medewerkers is egter so skaars! Dit plaas ook 'n onredelike verantwoordelikheid op die redaksiepersoneel se skouers wanneer hulle Afrikaanse ekwivalente vir Engelse terme aan die hand moet doen op gebiede wat vir hulle vreemd is. Waar is die Afrikaanssprekende chemici dan wat oor die kennis en ervaring beskik sodat hulle hier 'n onmisbare bydrae kan lewer?

Afrikaanssprekende natuurwetenskaplikes gebruik tog seker dikwels goeie Afrikaanse chemieterme sodat die samestellers nie hul koppe hoef te krap om eie vertalings voor te stel nie. Sulke vakspesialiste kan 'n waardevolle bydrae lewer om die chemievaktaal te verstewig en terselfdertyd hul kollegas se woordeskat te help uitbrei. Die projekleier hoor baie graag van chemici wat wil help deur terme uit vakhandboeke of -tydskrifte te ekserpeer, en/of Afrikaanse ekwivalente vir Engelse terme voor te stel, en/of kommentaar op rekenaarlyste met terme te lewer. Skryf gerus aan die Hoof, Afdeling Spesiale Dienste, IND, WNNR, Posbus 395, Pretoria, 0001 en bied u hulp aan. Reageer nou en bied $u$ hulp aan eerder as om later oor foute te wil kla. 